\title{
Foreign Direct Investment in the West African Region: Analyses on the Values of Inflow and Outflow
}

\author{
Yeboah Evans ${ }^{1} \&$ Yu Jing ${ }^{2}$ \\ ${ }^{1}$ School of Economics and Management, Nanjing University of Science and Technology, China \\ ${ }^{2}$ An Associate Professor in the School of Economics and Management, Nanjing University of Science and \\ Technology, China \\ Correspondence: Yeboah Evans, School of Economics and Management, Nanjing University of Science and \\ Technology, 200 Xiaolingwei Street,210094, Nanjing, Jiangsu Province, China. Tel: 86-136-4515-3161. E-mail: \\ yeboahevans56@yahoo.com
}

Received: April 3, 2020 Accepted: April 18, 2020 Online Published: May 8, 2020

\begin{abstract}
With regards to the ongoing development in investment activities in the Economic Community of West African States(ECOWAS) and the entire African continent is because of institutional reforms and initiation of sound investment policies. Foreign direct investment(FDI) inflow and outflow severs as a source of capital formation for most developing and least developed countries. This paper provides an overview and analyses of the flow of FDI to the ECOWAS region by considering 16 nations under this region in determining their performance towards FDI attraction and their contribution to outward FDI across the globe by the use of the quantitative method. The outcome shows that there is a continuous decline in FDI inflow to the ECOWAS region over the past 10 years. The result also proves that Ghana and Nigeria are the major recipients of foreign direct investment inflows in the West African region. The result further indicates that Nigeria is the major contributor of outward FDI from the ECOWAS region. It is recommended that the region should increase its outward FDI.
\end{abstract}

Keywords: FDI, ECOWAS, inflow, outflow, economy

\section{Introduction}

Concerning the recent development in most African countries' economies have attracted many investors on the continent. Foreign direct investment has become a significant foundation for capital formation of most developing nations and gradually outshining the over-dependence on foreign aids. Developing economies are rising and have a demand for resource and in many ways, capital will come into an economy through national borders, as it seeks the highest rate of return (Prince \& Vijay, 2019). FDI at some point in time plays a significant role in economic development support, including supporting local savings, job creation and advancement, integration into the global economy, modern technology transfer and improvement in the skilled local workforce (Hezron \& Pauline, 2016). In African countries, above all, besides being a crucial supply of long-term capital for investment in infrastructure and alternative biological process initiatives, FDI may be a catalyst for economic diversification, serving to these economies move on the far side overdependence on natural resources (John \& Nadege, 2015). As the African continent, not the major recipient of foreign direct investment flows and trails other regions in the world, FDI inflows not only vary across the sub-regions on the African continent but has shown great support and rapid expansion in numerous countries in West Africa. FDI inflows in Africa expanded by 4percent to 57 billion United States dollars powered by universal and regional market-searching and infrastructure investment (UNCTAD, 2010). However, according to the United Nations Conference on Trade and Development world investment report, foreign direct investment inflows to Africa were forecasted to expand slightly in 2017 as a result of modest rises in oil price and a potential increase in non-oil FDI. Foreign direct investment(FDI) decreased by $10 \%$ to $\$ 12.8$ billion in security problems and declining commodity prices adversely affected countries in West Africa (Unctad, 2015). As FDI inflows serve as a capital formation of many developing nations, this paper seeks to focus on the value (amount) received by countries in the West African region.

\section{Literature Review}

\subsection{Brief overview of the ECOWAS Region}

The West African region came as a result of the formation of the Economic Community of West African 
States(ECOWAS). Regional integration gives unique advantages to drive Africa's transformation and advancement. The Economic Community of West African States (ECOWAS) is among the major African Regional Economic Communities that has been shaping the evolution of regional integration in Western Africa (Dvelopment, 2018). The ECOWAS region has been a pivot of crisis prevention and management, financial and regional integration, to the free movement of people. Whiles the member states of the community now use three official languages (English, French and Portuguese), there are over thousand existing local languages including cross-border native languages such as Ewe, Fulfulde, Hausa, Mandingo, Wolof, Yoruba, etc. Which makes up more than 300 million people tucked in a vast area of about 5.1million square kilometers (Note 1). The Economic Community of West African States is purposely to foster interstate economic and political cooperation. Since the formation of ECOWAS in 1975, there have been 32 chairmen as the body is headed by a Chairman. However, the long vary objective of ECOWAS is to support the restructuring of the cooperating economies to attain complementarity between member states (Bruce, 1978). In terms of the development of member states, there are different levels of development concerning per capita income. The economic process of ECOWAS is driven by Nigeria, the community's largest economy, that in 2014 accounted for approximately 79.1 percent of the combined value, followed by Ghana 5.3\% and Cote d'Ivoire 4.7 percent (Dvelopment, 2018). Conversely, in the aspect of export, the community exports stood at $\$ 87.9$ billion as of 2015 and it accounted for $0.53 \%$ of the world total of which agricultural and extractive industries remain the backbone of economic and social development in the West African region. The aggregate worth of ECOWAS trade in goods(sum of exports and imports) is calculable at $\$ 190$ billion in 2015 while the regional trade depicted solely $\$ 19.1$ billion that is about 10\% of total trade (Dvelopment, 2018). Figure 1 below shows ECOWAS compared with the other regional economic communities in Africa.

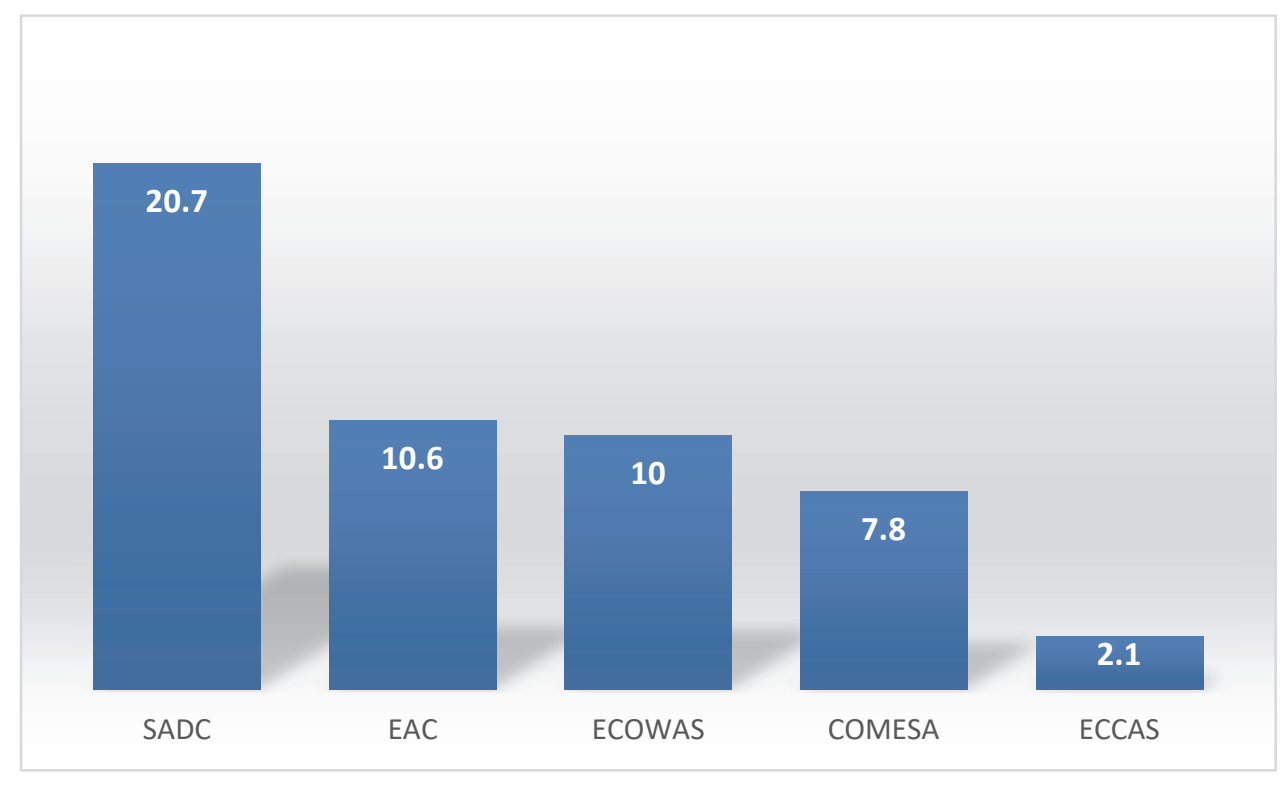

Figure 1. The share of intraregional trade in ECOWAS and selected RECs (2015 in percent) Source: UNCTADstat

\subsection{Trade Performance of ECOWAS}

Trade among nations is very significant for the economic growth and wellbeing of people. In the ECOWAS region, intragroup trade includes a few ranges of commodities such as fuel, tobacco, sea and river navigation equipment and cement. Petroleum as a single product accounted for $48.4 \%$ in 2015 (Dvelopment, 2018). According to the World Bank Global Economic Prospects report in January 2016 indicated that the existence of strong informal cross-border trade connections between Nigeria and neighboring nations are partially captured in official statistics. The assumptions of informal cross-border trade in the West African region indicate that it could represent $20 \%$ of the gross domestic product in Nigeria and 75\% of GDP in Benin (Dvelopment, 2018). The trade structure of ECOWAS with other parts of the world is controlled by export destinations mainly the European Union, China, India and the USA. The Economic Community of West African States exports leading destination is dominated by India as of 2015 with $14.8 \%$ share whereas, on the import side, the leading country of ECOWAS import is China accounted for $25 \%$ share in 2015. In 2015, the share of ECOWAS member intraregional trade for export were $44.6 \%$ 
from Nigeria, 25.7\% from Cote d'Ivoire, 2.8\% from Niger, Mali 1.6\%, Liberia $0.03 \%$, Guinea-Bissau $0.01 \%, 0.6 \%$ from Guinea, Ghana 4.5\%, 0.2\% from Gambia, Cabo Verde 0.01\%, 1.4\% from Burkina Faso, Benin 4.8\%, Togo $5.2 \%$, Sierra Leone $0.02 \%$ and $8.5 \%$ from Senegal. On the other hand, on the import percentage share Ghana had 25.7\%, Cote d'Ivoire 18.4\%, Burkina Faso 11.3\%, Nigeria 14\%, Mali 9.5\%, Niger 6.7\%, Liberia $0.4 \%$, GuineaBissau 0.3\%, Guinea 1.2\%, Gambia 0.6\%, Cabo Verde 0.1\%, Benin 3.3\%, Togo 1.2\%, Sierra Leone $1.8 \%$ and 5.5\% for Senegal.

\subsection{Ghana at a Glance}

Ghana is a democratic nation that gained independence from the British in 1957. Right after the country attained its freedom, there were several military regimes for 27 years. In 1992 there was an establishment of a constitution that brought about general elections through which, people are allowed to vote for their favorite candidate. However, over the past 19 years, Ghana has witnessed a free exchange of power between different political parties. There are two major religions which are Christianity and Islam. As of 2018, the country's population stood at 29.767 million. According to the United Nations Conference on Trade and Development Ghana's gross domestic product (GDP) valued at $\$ 65760$ million, CPI and GDP growth rate was at $9.84 \%$ and $6.50 \%$ respectively. Gross Domestic Product(GDP) per capita from 2016 to 2018 was $\$ 2064$. The export structures of products grouped in 2018 were 25 percent of all food items, $4 \%$ of ores and metal, $4 \%$ of fuel, 36 percent and $31 \%$ of manufactured goods and others, respectively. However, in 2017, breakdown in the economy total exports by main commodity groups were 26.4 percent of agricultural products, fuels and mining products $28.3 \%$, manufactures $6.7 \%$ and other products accounted for 38.6 percent whereas as Ghana's imports in the same year were 19.3 of agricultural products, fuels and mining products $3.8 \%$ and 76.8 percent of manufactured products.

Ghana's economic condition began to improve with the severity of manner programs in 1980 but the early 1990s brought new challenges including a decrease in the international cocoa price. The commodity value shock in1999 may be a clear example- between 1998 and 2000, a declined in the international cost affected the economy with a negative twenty percent in Ghana's gross domestic growth rate (IMF, 2012). Ghana's economy continues to expand in 2019 because of the $1^{\text {st }}$ quarter gross domestic product growth was forecasted at 6.7 percent, compared with 5.4 percent in the same period of 2018. The government of Ghana continued with its monetary fiscal consolidation effort in 2019 although there were still challenges in meeting the revenue targets. Fiscal result for the first half of 2019 showed an overall(cash-based) budget deficit of $3.3 \%$ of the gross domestic product above the $2.9 \%$ of gross domestic target, and this is because of the $1.6 \%$ of the GDP revenue shortfall was greater than $1 \%$ of the gross domestic product cut (Note 2). As of 2017, the great growth momentum has consistently placed Ghana among the 10 fastest growing economies in Africa and advancement in the macroeconomic climate has been followed by an increase in domestic demand due to higher private consumption (Note 3). Under, Ghana's economy there are different sectors within it. However, three major sectors that contribute significantly to the country's development and this includes the agricultural sector, industry sector, and service sector. In the Ghanaian economy, the service sector remains the largest sector in the aspect of the GDP sectoral share contribution of which its share of GDP expanded from $46 \%$ in 2017 to $46.3 \%$ in 2018. The sector's GDP growth rate decreased from 3.3 percent in 2017 to 2.7 percent in 2018 (GSS, 2019). The Services sector remained the largest sector of the Ghanaian economy in the second quarter of 2019 with a share of 49.1 percent of GDP at basic prices. The GDP share of Industry and Agriculture was 35.6 percent and 15.3 percent respectively (Service, 2019).The manufacturing sector(industry), the highest growing sector with $34 \%$ share of the gross domestic product saw its growth rate decreasing from $15.7 \%$ in 2017 to $10.6 \%$ in 2018. This could be attributed to the fall in the growth rate of the Oil and Gas activities from 80.3 percent in 2017 to 3.6 percent in 2018 (GSS, 2019). The agriculture sector increased by $4.8 \%$ in 2018 compared to a $6.1 \%$ growth rate in 2017 and a decline in its percentage share of the gross domestic share of $21.1 \%$ in 2017 to $19.7 \%$ in 2018. Crops is the second largest activity in Ghana with a share of 14.5 percent of GDP and the fishing sub-sector continued to contract, recording a GDP growth rate of -6.8 percent in 2018 from a growth rate of $-1.4 \%$ in 2017 (GSS, 2019). Table 1 below shows Ghana's main export and import destinations whereas figure 2 shows the sectoral distribution of nominal GDP.

Table 1. Export and import main destinations in 2018

$$
\text { Export Destination } \quad \text { Import Destination }
$$

European Union $36.6 \%$

India $17.9 \%$
European Union $43.5 \%$

China $18.7 \%$ 
United States of America 12.8\%

South Africa 4.5\%

Canada 3.5\%

Other $24.9 \%$
India $4.9 \%$

United States of America 8\%

Brazil 2.6\%

Other $22.4 \%$

Source: WTO

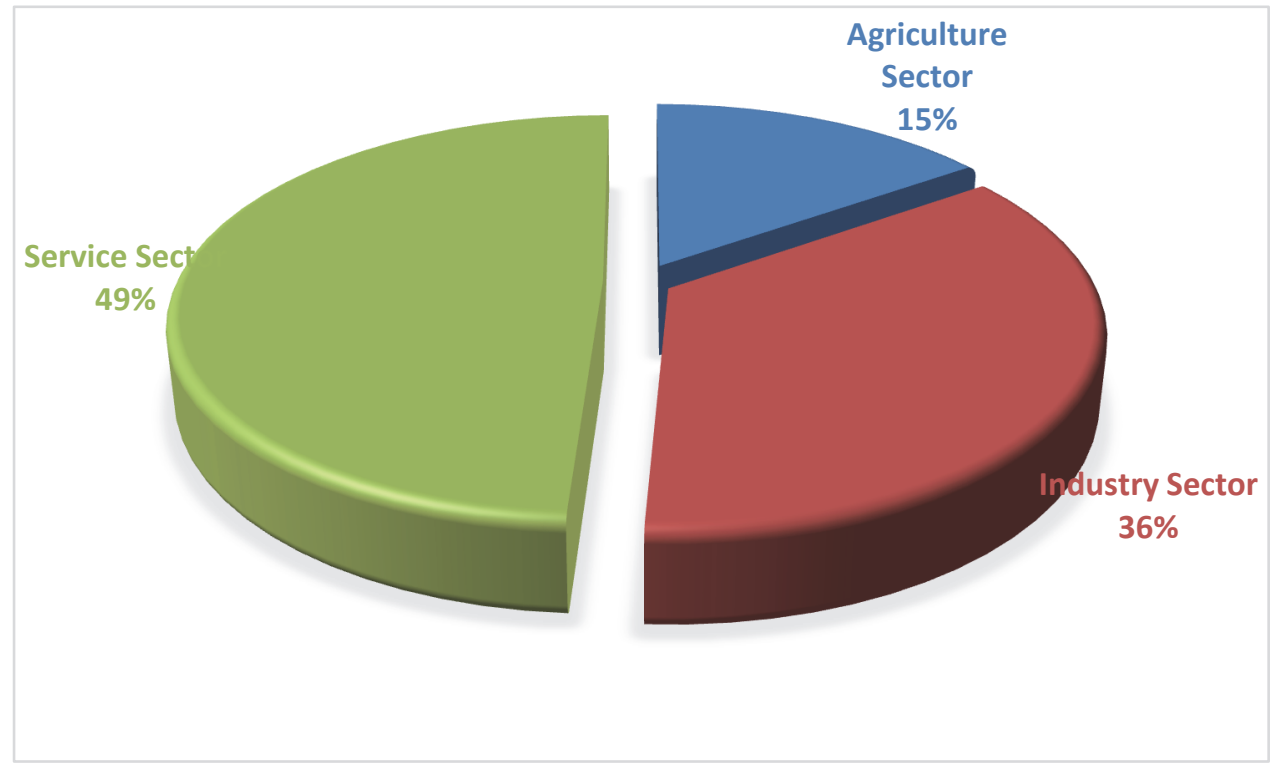

Figure 2. Sectoral distribution percentage of nominal GDP at basic price

Source: Ghana Statistical Service

\subsection{Nigeria at a Glance}

Nigeria, which is officially known as the federal republic of Nigeria, is a nation in the West African sub-region shares borders with Niger to the north, Chad in the northeast, Cameroon in the east and Benin in the west. However, the country gained independence from its colonial masters (the British) on 1st October 1960 which is marked as a holiday every year. Nigeria is the largest economy in the Africa continent followed by South Africa. The country's population as of 2018 was estimated to be 195.875 million with a land area of 910770-kilometer square. According to United Nations Conference on Trade and Development statistics, Nigeria's gross domestic product in 2018 valued at \$421694 million, with the consumer price index(CPI) and gross domestic product(GDP) growth at 12.09 percent and 1.90\% respectively. Gross domestic product per capita from 2016 to 2018 was 2082 United States dollars. The country's share of the world's total export and import represented $0.31 \%$ and $0.21 \%$ in 2018 . Fuels and mining products are the major trading commodities by Nigeria. The export structure of products breakdown in economies by main commodity group in 2017 were agricultural product 2percent, fuel and mining products $91.2 \%$, Manufactures $6.8 \%$ and other product $0.1 \%$ whereas imports by main products were agricultural products $12 \%$, fuels and mining products 21.7 percent, manufactures $35.8 \%$ and other products $30.5 \%$. Nigeria's economy depends heavily on crude oil as its main source of foreign exchange earnings and government revenue. The country is very vulnerable to fluctuations in international prices and demand for oil and gas, which accounts for more than 90 percent of export earnings and the greater part of federal revenue (Note 4). From 1997 to 1998, Nigeria's economy was in a crucial situation, once self-sufficient in food, the nation became a major importer of food. However, in the middle of 1999, with the support of the International Monetary Fund, the World Bank, and Nigerian government committed itself to reforming and restructuring policies, including privatization of state businesses and agriculture modernization. Real GDP growth was estimated at $2.3 \%$ in 2019 , marginally higher than $1.9 \%$ in 2018 and growth was mainly in transport, an improved oil sector, and information and communications technology (Note 5). Agriculture suffered by sporadic flooding and by a conflict between herdsmen and farmers whereas the industry sector is constantly affected by lack of financing. The poor performance of the agriculture sector weakens prospects for the rural poor, whilst huge food inflation negatively impacts the livelihoods of the urban poor. According to the World Bank oil price volatility consistently influence 
Nigeria's growth performance and between 2000 and 2014, the country's GDP grew at an average rate of 7 percent per year, following the fall of oil prices from 2014 to 2016, combined with an adverse production shock and the gross domestic growth rate declined to 2.7 percent in 2015. While Nigeria has gained some ground in socioeconomic terms as of late, its human capital advancement stays frail due to under-investment and the country positioned 152 of 157 nations in the World Bank's 2018 Human Capital Index (Note 6). Table 2 below shows Nigeria's main export and import destination whilst figure 3 indicates gross domestic product(GDP) by sector.

Table 2. Export and import main destinations in 2018

\section{Export Destination}

\section{Import Destination}

\begin{tabular}{cc}
\hline European Union $36.6 \%$ & European Union $43.5 \%$ \\
India $17.9 \%$ & China $18.7 \%$ \\
United States of America $12.8 \%$ & India $4.9 \%$ \\
South Africa $4.5 \%$ & United States of America $8 \%$ \\
Canada $3.5 \%$ & Brazil $2.6 \%$ \\
Other $24.9 \%$ & Other $22.4 \%$ \\
\hline
\end{tabular}

Source: WTO

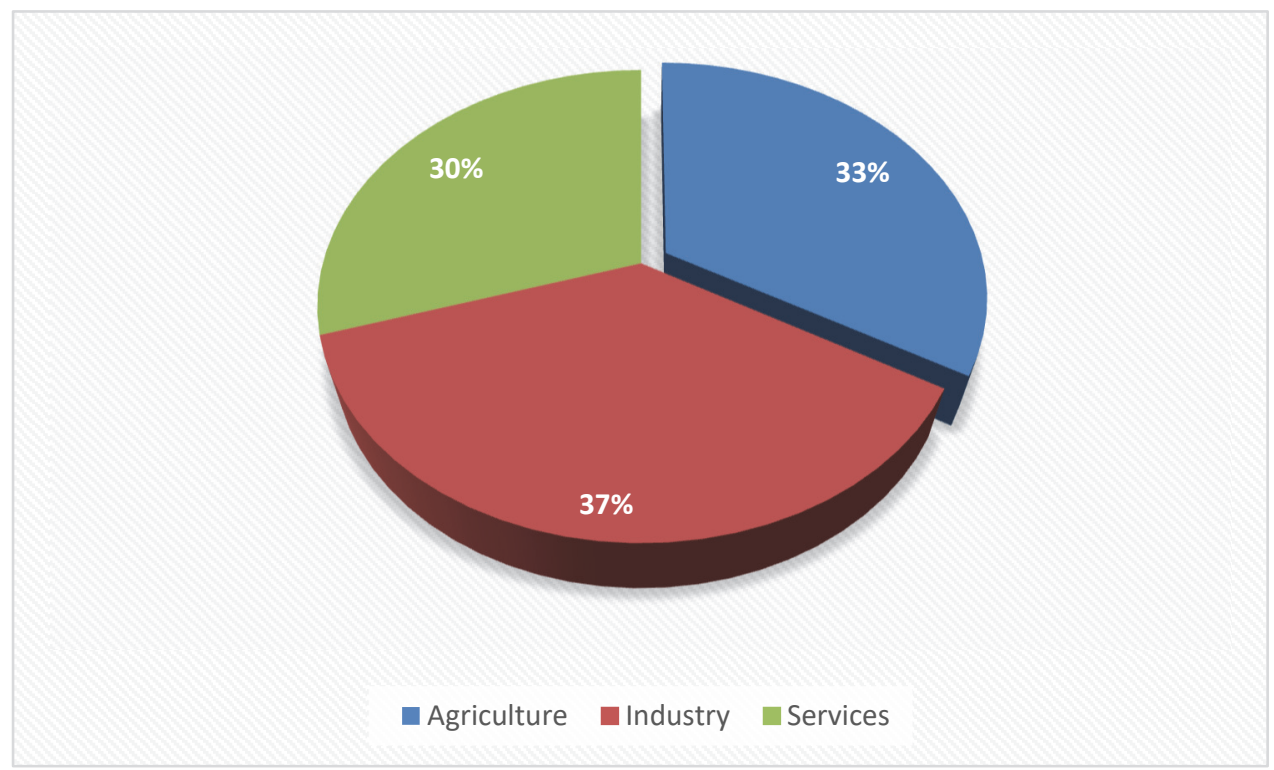

Figure 3. Gross Domestic Product by sector (2011)

Source: Commonwealth

\subsection{Empirical Works}

Exploring the determinants of foreign direct investment in 10 sub-Saharan economies by considering Cameroun, Cote d'Ivoire, Ghana, Liberia, Mali, Mauritania, Nigeria, Niger, Senegal, and Sierra Leone, and with a substantial literature review of empirical and theoretical works by the use of a set of cross-section data over the period 1990 to 2017, two econometric models are estimated with foreign direct investment(FDI)/gross domestic product(GDP). The outcome indicates that, the type of FDI attracted to invest in the region is evaluated from the practical and theoretical points of view (Prince \& Vijay, 2019).

Analyzing drivers of foreign direct investment to West Africa by applying a panel data-set from 1970-2010 using OLS and GMM techniques for the estimations, of which the result shows that, there is a U-shaped relationship between economic advancement and foreign direct investment inflow to West Africa (John \& Nadege, 2015).

Investigating the effect of FDI on economic growth in some selected African nations which include Central African Republic, Egypt, Kenya, Nigeria, and South Africa with a dataset from 1980-2014 and by the use of modified 
growth model, examining how nation-specific factors can explain variations in the growth advantages of foreign direct investment.; the effect of FDI on economic growth in these selected African countries is limited or negligible for OLS and dynamic panel estimation and the result further shows that South Africa's growth is more affected by foreign direct investment than in Nigeria (Olawumi, Olufemi, \& Theuns, 2017).

Providing panel data evidence on the determinants of FDI for a sample size of 45 nations in Africa from the period of 1980-2009 employing dynamic panel data estimation techniques, the result identifies some of the factors that affect foreign direct investment flows in Africa, including, agglomeration economies, natural resources, real gross domestic growth and international investment agreement (Moses \& Godbertha, 2012).

To answer the question of determinants of foreign direct investment in the West African economic and monetary union, which constituted eight nations and by the used of an econometric model based on panel cointegration analysis for the period of 1980 to 2010 was estimated ,of which the outcome shows that nations with high potential market size (gross domestic product per capita), large trade openness and with a more business-friendly atmosphere(low political risk) attract more foreign direct investment (Laleye \& Akinleye, 2018).

A panel data from thirty-eight Sub-Saharan African nations and with the use of dynamic system GMM model to examine the individual and interactive effect of financial development, institutional quality, and natural resource abundance on both the stock and the inflow of foreign direct investment to the region; the finding shows that inward foreign direct investment is more dynamic in non-resource-rich than in resource-rich nations (Abel \& Nicolette, 2012).

Using panel data spanning from 2001-2015 for the Economic Community of West African States, the study results from Pedroni co-integration test indicate that there is a cognate relationship between all the factors under investigation concerning the ECOWAS region (Hussaini, 2018).

In conclusion, there is a general agreement from studies that, foreign direct investment has a positive impact on a country's economic growth in the long run. In short, most of the studies focused on determinants and impact of FDI on the gross domestic product of countries in Africa without assessing their performance towards FDI attraction as well as their contribution toward outward FDI across the globe.

\section{Research Methodology and Data Source}

This study is focused on the analysis of FDI inflow and outflow in the West African region and its contribution to the world's development. Observing the trend of FDI flow to 16 selected countries and their contribution to economic growth. As the pattern of FDI becomes complicated to observe as a result of changes in data on the various countries annually, for this paper, there is a significant data available for these nations concerning foreign direct investment inflows and outflows in the ECOWAS region. In this situation, to execute the target outlined for this study, a quantitative method is considered. The analysis was based on the largest exporting country(Nigeria) in the ECOWAS region and Ghana the major recipient of FDI inflows in 2018. On the other hand, all the 16 countries FDI inflow and outflow were taken into account.

The set of data for this research work was generated from a secondary source and with the majority of the information collected from the United Nations Conference on Trade and Development responsible for providing a yearly report on FDI inflow and outflow across the globe. The trade data for Nigeria and Ghana were obtained from the World Integrated Trade Solution. Accordingly, other published papers and literature were also considered. The set of data for the analyses was from the period of 2009 to 2018.

\section{Result}

\subsection{Ghana and Nigeria Imports and Exports}

Over-dependence on the importation of manufactured products, telecommunication services, skilled personnel and other useful products has become a major challenge for many developing nations within the West Africa region and the entire African continent. Conversely, since the formation of ECOWAS Ghana and Nigeria have contributed much to the region's export and import. However, export is an important factor in economic development, and in 2015 both countries were ranked among the top export member share of cross-border and intraregional trade. Table 3 below indicates the exports and imports of both countries. 
Table 3. Ghana and Nigeria total export and import from 2009 to 2018

\begin{tabular}{|c|c|c|c|c|c|}
\hline \multirow[t]{2}{*}{ Year } & \multicolumn{2}{|r|}{ Ghana } & \multirow[t]{2}{*}{ Year } & \multicolumn{2}{|c|}{ Nigeria } \\
\hline & Exports (US\$ thousand) & Imports (US\$ thousand) & & Exports(US\$ thousand) & Imports(US\$ thousand) \\
\hline 2010 & $5,233,390.06$ & $8,057,140.73$ & 2010 & $86,567,912.53$ & $44,235,268.67$ \\
\hline 2011 & $18,146,652.69$ & $12,602,676.33$ & 2011 & $125,641,031.18$ & $63,971,541.90$ \\
\hline 2012 & $15,761,184.04$ & $13,578,112.62$ & 2012 & $143,151,182.81$ & $35,872,509.44$ \\
\hline 2013 & $12,643,899.38$ & $12,787,233.40$ & 2013 & $90,554,484.84$ & $44,598.201 .12$ \\
\hline 2014 & - & - & 2014 & $102,878,499.71$ & $46,532,265.38$ \\
\hline 2015 & - & - & 2015 & - & - \\
\hline 2016 & $10,655,796.41$ & $11,361,004.40$ & 2016 & $32,883,045.47$ & $35,194,301.01$ \\
\hline 2017 & $14,358,509.95$ & $12,718,141.84$ & 2017 & $44,466,366.76$ & $31,270,090.27$ \\
\hline 2018 & $17,099,588.40$ & $11,880,470.76$ & 2018 & $62,399,742.74$ & $43,011,523.21$ \\
\hline
\end{tabular}

\section{Source: WITS}

Note: In the table 3 above there were no records available on the World Integrated Trade Solution for Ghana's import and export from 2014 to 2015 and on the other hand, Nigeria's export and import for 2015 were also not available.

\subsection{FDI Inflows to West Africa}

Foreign direct investment inflows to the African continent increased to US $\$ 46$ billion in 2018 which represents an 11 percent rise in the value in 2017. According to the United Nations Conference on Trade and Development, while foreign direct investment(FDI) inflow to some big economies such as Nigeria and Egypt contracted, this was outweighed by a surge inflow to other nations, mostly South Africa. FDI inflow to West Africa decreased by 15 percent, to US $\$ 9.6$ billion, greatly as a result of Nigeria where flows jumped by 43 percent to US\$2 billion, and inflow to Ghana also declined through by a more average 8 percent to US $\$ 3$ billion. From 2009 to 2018 , there has been a total amount of US\$132,882.4million of FDI inflow to the West African region. Table 4 below shows the breakdown of FDI inflow to each of the countries whilst figure 4 shows West Africa's performance when it comes to the FDI inflows on the African continent.

Table 4. FDI inflow breakdown for West Africa countries from 2009 to 2018

\begin{tabular}{|c|c|c|c|c|c|c|c|c|c|c|}
\hline Country & $\begin{array}{c}2009 \\
\text { US\$M }\end{array}$ & $\begin{array}{c}2010 \\
\text { US\$M }\end{array}$ & $\begin{array}{c}2011 \\
\text { US\$M }\end{array}$ & $\begin{array}{c}2012 \\
\text { US\$M }\end{array}$ & $\begin{array}{c}2013 \\
\text { US\$M }\end{array}$ & $\begin{array}{c}2014 \\
\text { US\$M }\end{array}$ & $\begin{array}{c}2015 \\
\text { US\$M }\end{array}$ & $\begin{array}{c}2016 \\
\text { US\$M }\end{array}$ & $\begin{array}{c}2017 \\
\text { US\$M }\end{array}$ & $\begin{array}{c}2018 \\
\text { US\$M }\end{array}$ \\
\hline Benin & 134.3 & 176.8 & 161.1 & 281.6 & 360.2 & 405.2 & 149.7 & 131.7 & 200.4 & 207.5 \\
\hline $\begin{array}{c}\text { Burkina } \\
\text { Faso }\end{array}$ & 100.3 & 34.6 & 143.7 & 329.3 & 490.3 & 355.9 & 231.8 & 390.4 & 2.6 & 480 \\
\hline Cabo Verde & 174.3 & 158.8 & 154.7 & 125.6 & 69.6 & 180.4 & 115.8 & 127.2 & 111.2 & 99.6 \\
\hline $\begin{array}{c}\text { Cote } \\
\text { d'Ivoire }\end{array}$ & 377.1 & 338.9 & 301.6 & 330.3 & 407.5 & 438.8 & 494.2 & 577.5 & 927.6 & 912.9 \\
\hline Gambia & 39.4 & 37.1 & 36.1 & 41.2 & 25.5 & 35.6 & 12.5 & -27.7 & 17.7 & 29.1 \\
\hline
\end{tabular}




\begin{tabular}{ccccccccccc} 
Ghana & 2897.1 & 2527.4 & 3237.4 & 3293.4 & 3226.3 & 3357 & 3192.3 & 3485.3 & 3255 & 2989 \\
Guinea & 140.9 & 101.4 & 956.1 & 606.5 & 134 & 77.1 & 53.3 & 1618.4 & 577.4 & 482.7 \\
Guinea - & 17.5 & 33.2 & 25 & 6.6 & 19.6 & 28.9 & 18.6 & 24 & 15.7 & 17.3 \\
Bissau & & & & & & & & & & \\
Liberia & 217.8 & 450 & 785.3 & 984.6 & 1061.3 & 276.7 & 627 & 453.2 & 247.8 & 122.2 \\
Mali & 748.3 & 405.9 & 556.1 & 397.9 & 307.9 & 144 & 275.4 & 356.2 & 561.8 & 365.9 \\
Mauritania & -3.1 & 130.5 & 588.7 & 1388.6 & 1125.7 & 501 & 502.1 & 271.2 & 587.2 & 70.8 \\
Niger & 790 & 940.3 & 1065.8 & 841.3 & 719.1 & 821.9 & 529.3 & 301.1 & 337.9 & 460.1 \\
Nigeria & 8649.5 & 6099 & 8914.9 & 7127.4 & 5608.5 & 4693.8 & 3064.2 & 4448.7 & 3503 & 1997.5 \\
Senegal & 320.0 & 266.1 & 338.2 & 276.2 & 311.3 & 402.6 & 409 & 472.1 & 586.8 & 629.3 \\
Serra & 110.8 & 238.4 & 950.5 & $\mathbf{7 2 2 . 4}$ & 429.7 & 375.1 & 252.4 & 138 & 128.9 & 599 \\
Leone & & & & & & & & & & \\
Togo & 48.5 & 85.8 & 711.1 & 121.5 & 183.5 & 53.9 & 257.8 & -46.3 & 88.3 & 102 \\
Total & $\mathbf{1 4 , 7 6 4 . 2}$ & $\mathbf{1 2 , 0 2 4 . 3}$ & $\mathbf{1 8 , 9 2 6 . 3}$ & $\mathbf{1 6 , 8 7 4 . 3}$ & $\mathbf{1 4 , 4 7 9 . 9}$ & $\mathbf{1 2 , 1 4 7 . 9}$ & $\mathbf{1 0 , 1 8 5 . 3}$ & $\mathbf{1 2 , 7 2 1}$ & $\mathbf{1 1 , 1 9 4 . 3}$ & $\mathbf{9 , 5 6 4 . 9}$ \\
\hline
\end{tabular}

Source: UNCTAD

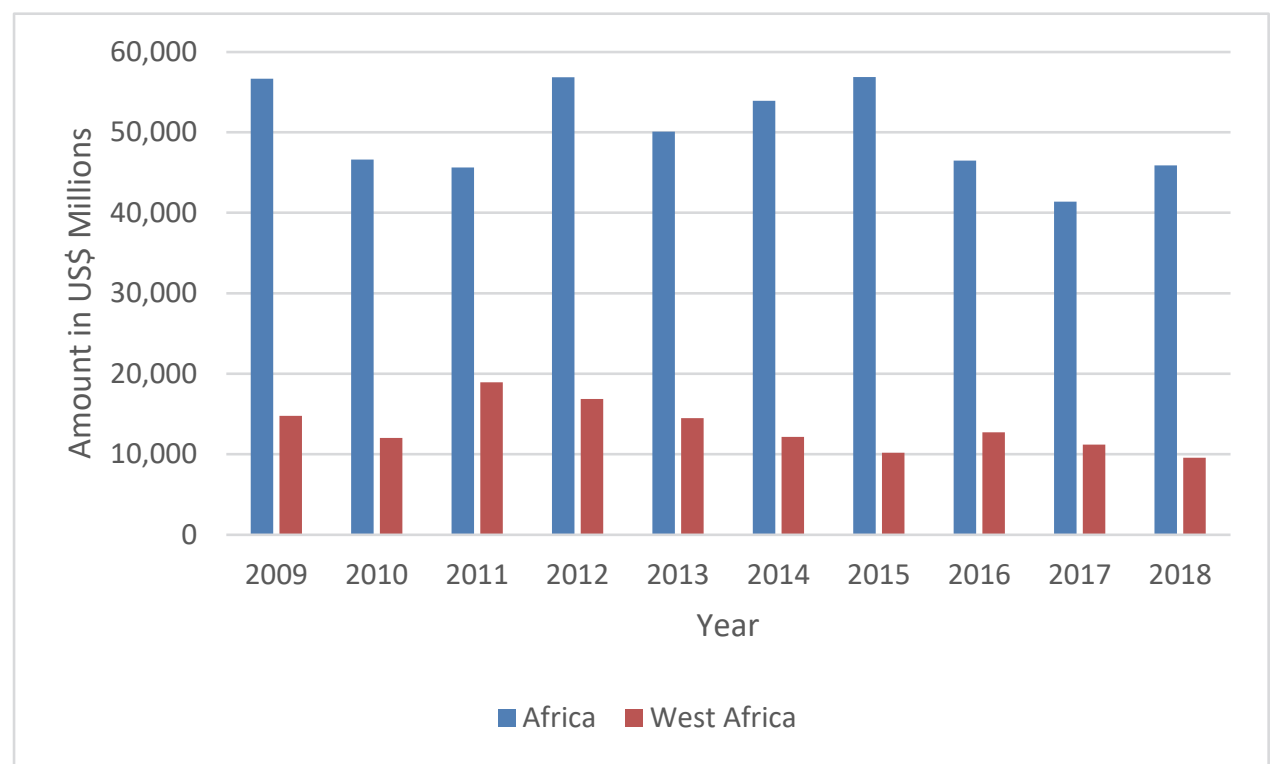

Figure 4. West Africa's performance towards FDI attraction on the African continent

Source: Author's calculations based on the data from UNCTAD

Figure 4 above shows that West Africa is performing well on the African continent. However, when determining the performance of the West African region and the total FDI inflow to Africa with the world's aggregate FDI inflows depict that Africa's share of foreign direct investment inflow is lower compared to Europe and Asia. Figure 5 below shows Africa performance toward FDI inflow in the world. 


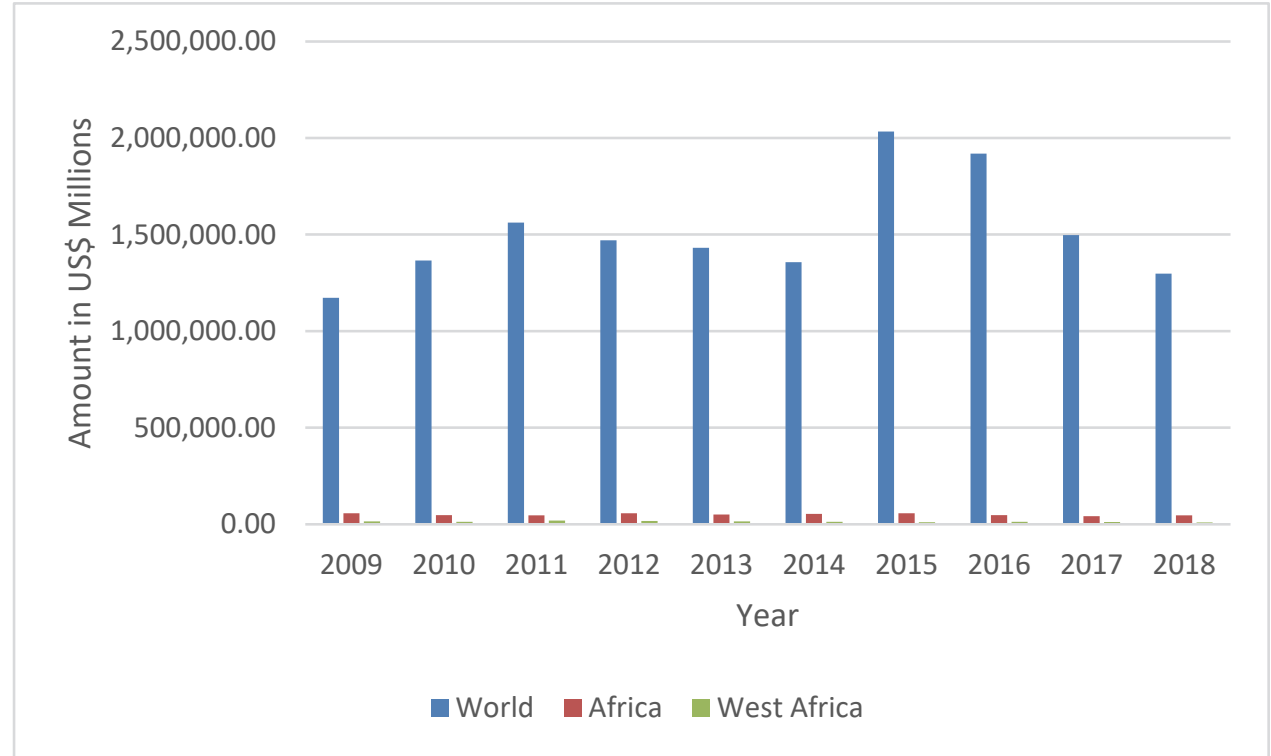

Figure 5. Africa's performance towards FDI attraction in the world

Source; author's calculations base on the data from UNCTAD

\subsection{FDI Outflow from West Africa}

Foreign direct investment outflow from African nations in 2018 declined by $26 \%$ to just about US $\$ 10$ and a significant decreasing outflow from Angola and South Africa, for the most part, accounted for the drop. According to the UNCTAD investment report in 2019 indicated that, from 2009 to 2018, there was a total amount of US\$ 22,876.1million FDI outflow from the West African region. Table 5 below indicates the breakdown of FDI outflow from each nation whereas figure 6 shows West Africa's contribution to FDI outflow from the African continent.

Table 5. FDI Outflow breakdown from West Africa countries from 2009 to 2018

\begin{tabular}{|c|c|c|c|c|c|c|c|c|c|c|}
\hline Country & $\begin{array}{l}2009 \\
\text { US\$M }\end{array}$ & $\begin{array}{l}2010 \\
\text { US\$M }\end{array}$ & $\begin{array}{l}2011 \\
\text { US\$M }\end{array}$ & $\begin{array}{l}2012 \\
\text { US\$M }\end{array}$ & $\begin{array}{l}2013 \\
\text { US\$M }\end{array}$ & $\begin{array}{l}2014 \\
\text { US\$M }\end{array}$ & $\begin{array}{l}2015 \\
\text { US\$M }\end{array}$ & $\begin{array}{l}2016 \\
\text { US\$M }\end{array}$ & $\begin{array}{l}2017 \\
\text { US\$M }\end{array}$ & $\begin{array}{l}2018 \\
\text { US\$M }\end{array}$ \\
\hline Benin & 31.2 & -17.9 & 59.6 & 40.3 & 58.6 & 17.3 & 32.7 & 17.4 & 31.8 & 24.3 \\
\hline Burkina Faso & 8.5 & -3.5 & 102.2 & 73.0 & 58.3 & 69.5 & 14.1 & 50.5 & 10.2 & 69.1 \\
\hline Cabo Verde & 0.8 & -0.0 & -1.4 & -7.7 & -13.8 & -8.2 & -3.9 & -9.1 & -13.6 & -19.8 \\
\hline Cote d'Ivoire & -9.5 & 24.9 & 15.3 & 14.3 & -6.4 & 16.2 & 14.7 & 28.6 & 674.4 & 317.8 \\
\hline Gambia & - & - & -58.2 & -10.0 & -49.1 & - & -22.8 & -1.4 & 7.5 & -5.6 \\
\hline Ghana & 6.9 & - & 25.4 & 1.1 & 8.8 & 11.8 & 221.4 & 14.7 & 15.9 & 81.0 \\
\hline Guinea & - & - & 1.5 & 2.9 & 1.1 & 2.1 & 4.1 & -4.4 & 0.9 & 0.0 \\
\hline Guinea- & -0.1 & 5.5 & 0.9 & -0.1 & 0.0 & 2.7 & 2.3 & 0.5 & 0.3 & 1.1 \\
\hline \multicolumn{11}{|l|}{ Bissau } \\
\hline Liberia & 363.6 & 1518.5 & -222.3 & 1388.4 & 327.1 & -35.5 & 30.4 & 167.7 & 54.2 & 84.1 \\
\hline Mali & -1.0 & 7.4 & 4.4 & 16.0 & 2.9 & 0.6 & 82.3 & 96.9 & 14.7 & 54.5 \\
\hline Mauritania & - & 16.8 & 1.5 & -2.7 & 18.6 & 27.7 & 0.2 & 1.0 & 9.7 & 3.6 \\
\hline Niger & 59.3 & -59.7 & 9.3 & 2.2 & 100.7 & 88.5 & 34.1 & 40.2 & 29.0 & 44.0 \\
\hline Nigeria & 1542.0 & 922.7 & 823.6 & 1542.6 & 1237.5 & 1614.3 & 1435.2 & 1305 & 1286.2 & 1380.9 \\
\hline Senegal & 77.1 & 2.2 & 47.5 & 56.0 & 33.3 & 27.4 & 31.4 & 223.7 & 82.2 & 72.9 \\
\hline
\end{tabular}




\begin{tabular}{lcccccccccc} 
Togo & 37.4 & 37.2 & 1059.8 & 420.3 & -20.7 & 358.5 & 348.5 & 256.8 & -32.5 & 259.5 \\
Total & $\mathbf{2 , 1 1 6 . 3}$ & $\mathbf{2 , 4 5 3 . 9}$ & $\mathbf{1 , 8 6 8 . 8}$ & $\mathbf{3 , 5 3 6 . 5}$ & $\mathbf{1 , 7 5 6 . 9}$ & $\mathbf{2 , 1 9 3 . 0}$ & $\mathbf{2 , 2 2 4 . 4}$ & $\mathbf{2 , 1 8 8 . 0}$ & $\mathbf{2 , 1 7 0 . 9}$ & $\mathbf{2 , 3 6 7 . 4}$ \\
\hline
\end{tabular}

Source: UNCTAD

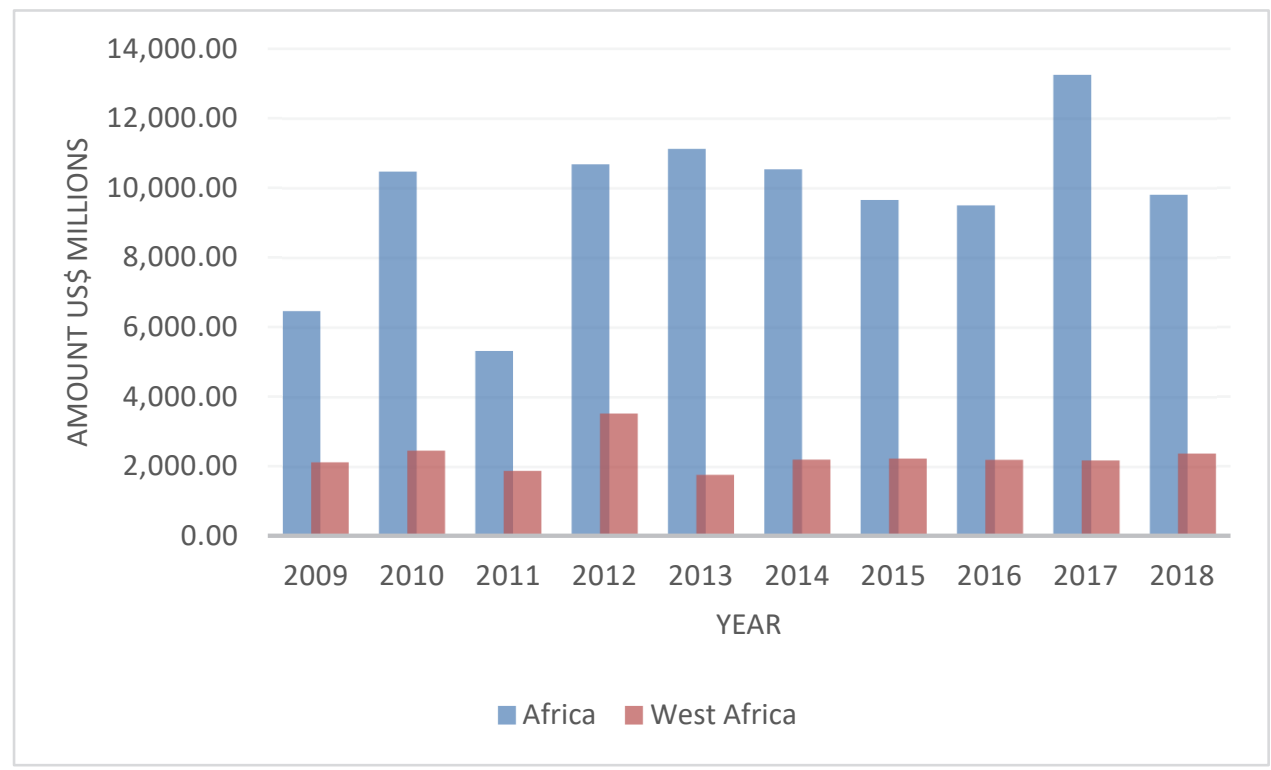

Figure 6. West Africa's contribution to FDI outflow from the African continent.

Source: Author's calculations based on the data from UNCTAD

Figure 6 above shows that West Africa is doing well on the African continent in terms of its contribution to outward FDI compared to other sub-regions such as Central and East Africa. However, in ascertaining the performance of the West African region and the total FDI outflow from the Africa continent with the world's aggregate FDI outflow indicates that Africa's share of FDI outflow is smaller compared to Europe and Asia. Figure 7 shows Africa contribution toward FDI outflow in the world.

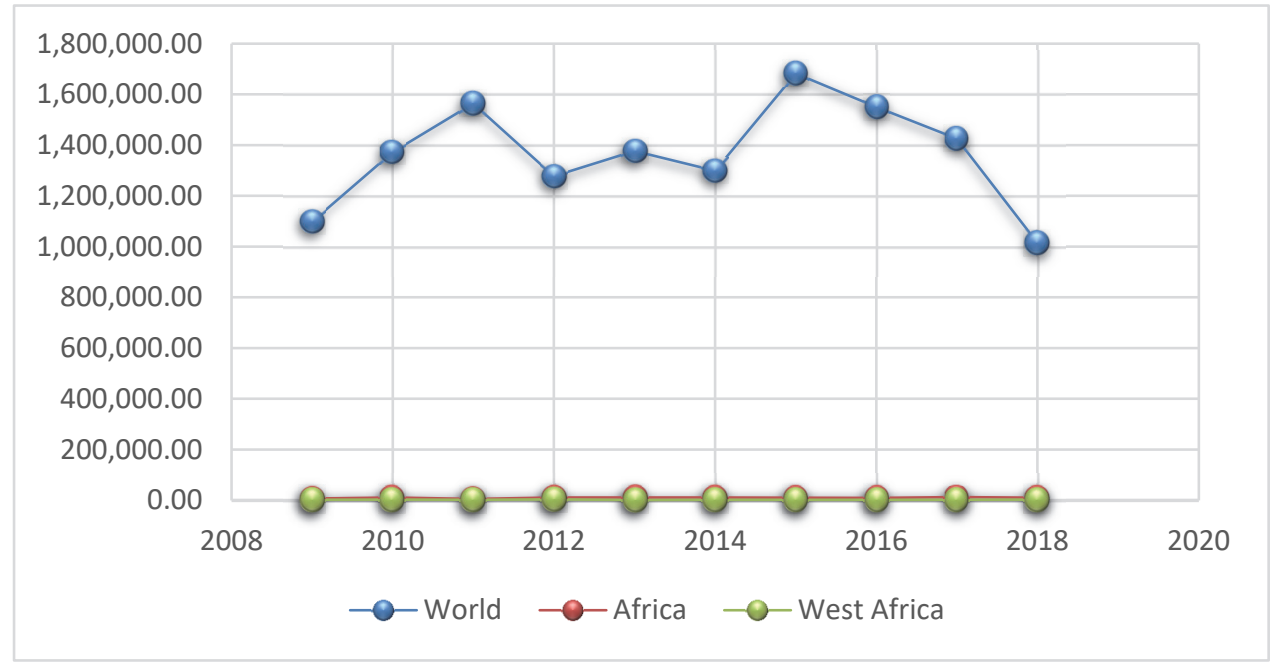

Figure 7. Africa's contribution to FDI outflow in the world.

Source: author's calculations base on the data from UNCTAD 


\section{Discussion on West Africa's Situation}

Considering the values of foreign direct investment inflows to the West African region, there are some instabilities in the total amount of FDI flow to the region over the past years. Inflows amount attained its maximum in 2011 and a continuous decline from 2012 to 2018. Practically, it is seen that, the West African region is performing well on a continental level but its amount of inflow is very insignificant on the international level. Considering the total flow of foreign direct investment into the Africa continent shows that, there is an indirect decrease in values over the past 10years. On the other hand, over-dependence on foreign direct investment inflow by many nations in the region and the entire continent has led to abysmal performance on outward FDI from Africa. However, the highest amount of outward foreign direct investment from Africa was in 2017 whereas West Africa contributed its total highest in 2012. In the situation, where there is less involvement in outward FDI by governments, multinational companies and individuals in Africa will lead to a lack of exploration of resource-seeking, marketseeking and efficiency-seeking in other parts of the world. Conversely, comparing the inflow and outflow of foreign direct investment in West Africa to Northern Africa and Southern Africa clearly shows that, the West African region is far behind these two regions.

\section{Conclusion}

The objective of this study is to be of importance to governments, various policy-makers, multinational companies and individual investors in the West African region, foreign investing countries, manufacturers and exporting nations producing some essential goods and services as well as other substantial investors that would like to gather much information on investment in the ECOWAS region and the African continent. As investment continues to increase on the African continent with a decline in the total amount received by the West African region has been something critical to be addressed. Conversely, outward foreign direct investment from the region harms the economy and local companies as they face stiff competition from foreign companies. The ECOWAS region should put in much effort to improve upon its investment policies and business environment to attract much inflow of FDI. A stable economy with a lack of available credit facilities and incentives to boost local and foreign investor's confidence level hinders the growth of FDI inflow and outflow. However, this may not be sufficient to capture the factors affecting the flow of foreign direct investment in the ECOWAS region and the entire African continent.

\section{References}

Abel, E. E., \& Nicolette, C. (2012). FDI Flows to Sub-Saharan Africa: The Impact of Finance, Institutions, and Natural Resource Endowment. Comparative Economic Studies, 54, 597-632. https://doi.org/10.1057/ces.2012.18

Bruce, Z. (1978). The Economic Community of West African States (ECOWAS): An Analysis and Prospects. Case Western Reserve Journal of International Law, 10(1).

Dvelopment, U. N. (2018). Regional Integration and Non-Tariff Measures in the Economic Community of West African States (ECOWAS). UNCTAD.

GSS. (2019). Rebased 2013-2018 Annual Gross Domestic Product. Accra: Ghana Statistical Service.

Hezron, M., \& Pauline, W. (2016). Role of foreign direct investment on technology transfer and economic growth in Kenya: a case of the energy secto. Journal of Innovation and Entrepreneurship, 5(31). https://doi.org/10.1186/s13731-016-0059-3

Hussaini, S. (2018). THE IMPACT OF FOREIGN DIRECT INVESTMENT ON ECONOMIC GROWTH OF WEST AFRICAN MEMBER STATE'S (A CASE STUDY OF ECOWAS) (2001 - 2015). International Journal of Business and Management Review, 6(11), 24-39.

IMF. (2012). World Economic Outlook: Growth Resuming, Dangers Remain. Washington DC: International Monetary Fund.

John, C., \& Nadege, D. (2015). What Drives Foreign Direct Investments into West Africa? An Empirical Investigation. African Development Review, 27(3), 199-215. https://doi.org/10.1111/1467-8268.12141

Laleye, N. A., \& Akinleye, S. O. (2018). Major Determinants of Foreign Direct Investment in the West African Economic and Monetary Region. Iran Economic Review, 22(1), 121-162.

Moses, M. S., \& Godbertha, K. (2012). Determinants of Foreign Direct Investment in Africa: A Panel Data Analysis. Global Journal of Management and Business Research, 12(18).

Olawumi, D., Olufemi, P., \& Theuns, G. (2017). Foreign direct investment and economic growth in Africa: a comparative analysis. Int.J.Sustainable Economy, 9(3), 183. https://doi.org/10.1504/IJSE.2017.085062 
Prince, J., \& Vijay, S. (2019). The Determinants of FDI in Sub-Saharan Economies: A Study of Data from 19902017. International Journal of Financial Studies .

Service, G. S. (2019). Newsletter Quarterly Gross Domestic Product (QGDP) Second Quarter 2019. Accra: GSS.

UNCTAD. (2010). Investing in Low-Carbon Economy. United Nations Conference on Trade and Development, 184.

Unctad. (2015). World Investment Report:Reforming International Investment Governance. New York and Geneva: United Nations Conference on Trade and Development.

\section{Notes}

Note 1. https://www.ecowas.int/about-ecowas/history/

Note 2. https://www.worldbank.org/en/country/ghana/overview\#1

Note 3. https://www.afdb.org/en/countries/west-africa/ghana/ghana-economic-outlook

Note 4. https://thecommonwealth.org/our-member-countries/nigeria/economy

Note 5. https://www.afdb.org/en/countries-west-africa-nigeria/nigeria-economic-outlook

Note 6. https://www.worldbank.org/en/country/nigeria/overview

\section{Copyrights}

Copyright for this article is retained by the author(s), with first publication rights granted to the journal.

This is an open-access article distributed under the terms and conditions of the Creative Commons Attribution license (http://creativecommons.org/licenses/by/4.0/). 